\title{
TERAPI BIRTH BALL UNTUK MENURUNKAN INTENSITAS NYERI PERSALINAN
}

\author{
Debora Paninsari ${ }^{1}$, Elsa Situmorang ${ }^{2}$, Deswita E.KC. Gulo ${ }^{3}$, Herfan \\ Feronika Bago ${ }^{4}$, Nelfian Laia ${ }^{5}$, Sri Swarti ${ }^{6}$ \\ 1,2,3,4,5,6 Fakultas Keperawatan dan Kebidanan Universitas Prima Indonesia \\ Corresponding author: \\ deborapaninsari@gmail.com
}

\begin{abstract}
Pain in childbirth has the highest degree of pain among other pain, so that many women are not ready to have children because they imagine the pain that will be presented at the time of labor later. The general objective of this study was to determine whether there was an effect of birth ball therapy on pain intensity in labor. Univariate and bivariate analysis using Wilcoxon test analysis. Bivariate analysis is used to see the effect of the independent variable (independent) on the dependent variable using the Wilxocon test analysis. Of the 50 respondent mothers who carried out the variable therapy pre-test birth ball who were very painful and 29 respondents had pain (58\%), and a minority of respondents had little pain, 21 people (42\%). And on the post-test respondents the least pain was increased by 32 respondents (64\%), while the minority of pain was quite severe as many as 18 respondents (36\%). A significant effect on the effect of birth ball therapy on labor pain where the p value is $0.00<0.05$. The results are expected to have an effect on birth therapy on labor pain. The results of the Wilcoxon test analysis with a degree of significance $(\alpha)=0.05$ and a $P$ value of 0.00 were obtained $(\alpha<0.05)$ which can be seen from the value which means that Ho is rejected and Ha is accepted. The conclusion is that there is an effect of birth ball therapy on labor pain.
\end{abstract}

Keywords: birth ball, pain intensity

\section{PENDAHULUAN}

Data World Health Organization (WHO), kematian ibu sebanyak 99\% diakibatkan oleh masalah persalinan atau kelahiran. Minimnya pengetahuan ibu tentang etiologi dan penanganan komplikasi kehamilan, persalinan dan nifas umumnya menyebabkan angka kematian yang tinggi. Mayoritas kematian ibu terjadi di Negara berkembang disebabkan keterbatasan menjangkau akses pelayanan kesehatan, kekurangan fasilitas, terlambatnya pertolongan persalinan disertai keadaan sosial ekonomi dan pendidikan masyarakat yang masih tergolong rendah(Indrayani T, 2019) . Penelitian ilmu International Conference On Indonesian Family Planning And Reproductive Health (ICIFPRH) hingga tahun 2019 Angka Kematian Ibu di Indonesia masih tetap tinggi, yakni 302 /100.000 kelahiran hidup. Sementara, target AKI Indonesia pada tahun 2015 adalah 102 per 100.000 
kelahiran hidup (Irawati et al., 2019).

Salah satu metode mengurangi nyeri persalinan yaitu menggunakan intervensi terapi birth ball. Didukung pendapat dalam jurnal yang berjudul efektifitas penggunaan birth ball akan berkurangnya nyeri persalinan kala pembukaan difase aktif pada kehamilan pertama terapi bola untuk ibu bersalin membantu ibu inpartu mempercepat kemajuan persalinan yang bisa dilakukan dalam berbagai posisi (Kurniawati A, 2017).

Menggunakan terapi bola berpengaruh dalam menurunkan skor nyeri ibu inpartu fase aktif kala pembukaan menunjukan bahwa dari 17 jumlah sampel penelitian ibu bersalin tanpa adanya kelompok kontrol, sebelum perlakuan birthing ball hasil skor nyeri responden menunjukkan rasa nyeri sangat banyak yaitu berjumlah 11 orang (64\%), sedangkan setelah penggunaan birthing ball responden mengalami nyeri tidak banyak yaitu terdapat 9 orang (53\%) (Marmi, 2016).

Berdasarkan latar belakang di atas penggunaan terapi bola ibu inpartu mengenai tingkat nyeri pada ibu melahirkan sangat mutlak dilakukan untuk menurunkan intensitas nyeri pada persalinan terutama pada lingkungan penelitian, sehingga penelitian tertarik dalam melaksankan penelitian tentang "Pengaruh Terapi Birth Ball Terhadap Intensitas Nyeri Pada Persalinan.”

\section{METODE}

ISSN 2599-1841

Jenis penelitian ini adalah penelitian pre-eksperimen. Desain penelitian preeksperimen ini menggunakan rancangan one shot case study, penelitian ini desainnya dengan suatu kelompok diberi treatment/ perlakuan, dan kemudian hasilnya di observasi (Jiwantoro, 2017). Lokasi penelitian dilaksanakan pada 2 Oktober sampai dengan 5 November 2020 di Praktik Mandiri Bidan Supiani Medan. Populasi sejumlah 50 orang dan Teknik sampling yang digunakan adalah total sampling. Aspek pengukuran Pengaruh terapi birth ball Terhadap intensitas nyeri pada persalinan yang menjalani terapi birth ball di ruang bersalin klinik pratama hana kasih medan tahun 2020, dengan menggunakan FPRS. Aspek pengukuran menggunakan FPRS yaitu (1) tidak ada nyeri yang dirasakan, jika ekspresi wajah 0 ; (2) sedikit nyeri, jika ekspresi wajah 1; (3) nyeri, jika ekspresi wajah 2; (4) nyeri lumayan parah, jika ekspresi wajah 3 ; (5) nyeri parah, jika ekspresi wajah 4 ; (6) nyeri sangat parah, jika ekspresi wajah 5 (Judha MSA, 2019). Pengumpulan Data menggunakan kuisoner dan lembar observasi. Analisis data secara univariat dan bivariat dengan menggunakan uji wilxocon. 


\section{HASIL DAN PEMBAHASAN}

Tabel 1. Distribusi frekuensi berdasarkan intensitas nyeri sebelum dan sesudah perlakuan birthingBall

\begin{tabular}{llcrrr}
\hline Skor & Tingkat Nyeri (FPRS) & Pre & \multicolumn{2}{c}{ Post } \\
& & n & \% & n & \% \\
\hline 0 & Tidak nyeri & 0 & 0 & 0 & 0 \\
1 & Sedikit nyeri & 21 & 42 & 32 & 73 \\
2 & Nyeri & 0 & 0 & 0 & 0 \\
3 & Nyeri lumayan parah & 29 & 58 & 8 & 27 \\
4 & Nyeri parah & 0 & 0 & 0 & 0 \\
5 & Nyeri sangat parah & 0 & 0 & 0 & 0 \\
\hline & Total & $\mathbf{5 0}$ & $\mathbf{1 0 0}$ & $\mathbf{3 0}$ & $\mathbf{1 0 0}$ \\
\hline
\end{tabular}

Berdasarkan Tabel 1 diatas dapat dilihat bahwa mayoritas responden pre test yang mengalami nyeri lumayan parah sebanyak 29 responden (58\%), sedangkan minoritas responden pre test yang merasakan sedikit nyeri sebanyak 21 responden $(42 \%)$.

Tabel 2. Distribusi Frekuensi Responden Terapi Birth Ball Sebelum Dan Sesudah Dilakukan

\begin{tabular}{|c|c|c|c|}
\hline No & Variabel & Frekuensi & Presentase \\
\hline \multicolumn{4}{|c|}{ 1. Pre } \\
\hline & a. Sedikit nyeri & 21 & 42 \\
\hline & b. Nyeri lumayan parah & 29 & 58 \\
\hline & Total & 50 & 100 \\
\hline
\end{tabular}

2. Post

\begin{tabular}{cccc} 
a. & Sedikit nyeri & 32 & 64 \\
b. & Nyeri lumayan parah & 18 & 36 \\
\hline & Total & 50 & 100 \\
\hline
\end{tabular}

Keterangan : pre $=$ sebelum; post $=$ sesudah

Berdasarkan tabel 2 diatas dapat kita simpulkan bahwah dari variabel pre test mayoritas responden nyeri lumayan parah 19 orang $(63 \%)$, sedangkan minoritas responden sedikit nyeri 11 orang (37\%). Dan pada responden post test mayoritas sedikit nyeri menjadi bertambah yaitu sebanyak 22 responden
Pada post test mayoritas responden yang merasakan sedikit nyeri sebanyak 32 responden (64\%), sedangkan minoritas responden yang merasakan nyeri lumayan parah sebanyak 18 responden (36\%). 
Table 3. Pengaruh Terapi Birth Ball Terhadap Intensitas Nyeri Persalinan

\begin{tabular}{lcccccr}
\hline Intensitas & \multicolumn{2}{c}{ Pre } & & Post & P Value \\
Nyeri & \multicolumn{2}{c}{ n } & $\mathbf{\%}$ & n & \% & \\
\hline SN & 21 & 42 & 32 & 64 & 0,05 \\
NLP & 29 & & 58 & 18 & 36 & 0,00 \\
Total & $\mathbf{5 0}$ & & $\mathbf{1 0 0}$ & $\mathbf{5 0}$ & $\mathbf{1 0 0}$ & \\
\hline
\end{tabular}

Berdasarkan Tabel 3 diatas dapat dilihat bahwa nilai Asymp. Sig. (2-tailed) adalah 0,00. Selain itu, berdasarkan perbedaan signifikasinya ( $p$ value), pada kelompok pre test didapatkan $\mathrm{P}$ value $=0,05$ dan pada kelompok post test di dapatkan $\mathrm{P}$ value $=0,00$. Sehingga dapat disimpulkan $0,00<0,05$, dapat diambil kesimpulan bahwa Ha diterima dan Ho ditolak. Maka dari itu dapat diartikan bahwa terdapat pengaruh perlakuan dari terapi birth ball terhadap intensitas nyeri persalinan.

Hasil penelitian Di Klinik Pratama Hanna Kasih Medan 2020 didapatkan bahwa dari variabel pre test mayoritas responden nyeri lumayan parah 29 orang (58\%), sedangkan minoritas responden sedikit nyeri 21 orang $(427 \%)$. Dan pada responden post test mayoritas sedikit nyeri menjadi bertambah yaitu sebanyak 32 responden (64\%), sedangkan minoritas nyeri lumayan parah sebanyak 18 responden $(36 \%)$.

Berdasarkan hasil uji wilcoxon test dengan derajat kemaknaan $(\alpha)=0,05$ dan $P$ value 0,00 diperoleh $(\alpha<0,05)$ dapat disimpulkan nilai yang berarti Ho ditolak dan Ha diterima.

Terapi birth ball yang dilakukan ibu bersalin dengan melakukan duduk dan bergoyang diatas bola, merangkul bola selama kontraksi dapat memberikan manfaat membantu ibu dalam mengurangi rasa nyeri saat persalinan (Noviyanti, 2020).

Ibu yang dapat melakukan relaksasi seirama kontraksi uterus berlangsung akan merasa lebih nyaman selama berlangsungnya persalinan. Selain itu birth ball sangat membantu penurunan nyeri saat pembukaan pada kala 1, birthing ball mempunyai manfaat lain diantaranya dapat menurunkan angka kala I memanjang, merangsang kontraksi uterus, mempercepat pembukaan serviks, melebarkan diameter panggul serta membantu penurunan kepala janin, sehingga penggunaan birthing ball sangat direkomendasikan terutama pada ibu hamil, bersalin dan nifas (Rosiena GA, 2019).

Dengan demikian menghubungkan hasil dari penelitian yang dilakukan peneliti bahwa didapatkan 8 responden yang tidak mengalami penurunan nyeri yang disebabkan oleh ketidak mampuan ibu dalam melakukan relaksasi seirama kontraksi uterus berlangsung (Sutriningsih, 2019).

Rasa tidak nyaman ibu inpartu bisa di atasi menggunakan gaya tubuh yang 
menopang gravitasi dan posisi yang membantu percepatan dilatasi serviks contohnya melakukan posisi berlutut, jalan santai, duduk dan jongkok. Menggunakan birth ball pada posisi tersebut selama proses persalinan dapat membantu ibu untuk merasa lebih nyaman (Sari, 2019).

\section{KESIMPLAN DAN SARAN}

Terdapat pengaruh yang kuat antara pengaruh pelaksanaan terapi bola akan penurunan skor nyeri persalinan dimana nilai $p$ value $0,000<0,05$.

Disarankan kepada ibu bersalin dapat menggunakan metode terapi bola untuk mengurangi nyeri persalinan

\section{DAFTAR PUSTAKA}

Indrayani T, R. M. (2019). Pengaruh Penggunaan Birthing Ball Terhadap Penurunan Skor Nyeri Pada Ibu Bersalin Kala I Fase Aktif Di Klinik Bersalin Bekasi Tahun 2018. HealthyMu Journal, 5(1), 3-8.

Irawati, A., Susanti, S., \& Haryono, I. (2019). Mengurangi Nyeri Persalinan dengan Teknik Birthing Ball. Jurnal Bidan Cerdas (JBC), 2(3), 129. https://doi.org/10.33860/jbc.v2i3.282
Jiwantoro, Y. (2017). Analisis Data Statistic Menggunakan SPSS. Mitra Wacana Medika.

Judha MSA. (2019). Teori Pengukuran Nyeri Persalinan. Nuha Medika.

Kurniawati A. (2017). Efektifitas latihan birth ball terhadap penurunan nyeri persalinan kala I fase aktif pada primigravida. 5(1), 10-11.

Marmi. (2016). Intranatal Care Asuhan Kebidanan pada Persalinan. In Pustaka Pelajar.

Noviyanti. (2020). Kebidanan komplementer:pengurangan nyeri persalinan dengan latihan birth ball. 14, 226-228.

Rosiena GA. (2019). Pengaruh birthing ball terhadap lama kala I fase aktif pada primigravida. 8(2), 164-175.

Sari, W. (2019). Pengaruh senam hamil menggunakan bola persalinan terhadap persepsi nyeri persalinan dan efikasi diri primigravida. 4(1).

Sutriningsih. (2019). Wellness and healthy magazine. 1(1). 
Jurnal Maternitas Kebidanan, Vol 6, No. 1, April 2021

ISSN 2599-1841 